\title{
Okun's Law revisited
}

\author{
Graeme Chamberlin
}

Office for National Statistics

\section{Summary}

The relationship between changes in output and the unemployment rate is of significant interest around times of recession and economic recovery. This article looks at various aspects of this relationship over time, across various constituents of the labour market and across different countries. The article also explores the interactions between changes in the unemployment rate with the household population, economic activity rate, average hours and labour productivity in accounting for recent output movements in the UK economy and how these compare to previous recessions and recoveries.

\section{Introduction}

Empirical relationships regarding unemployment have long fascinated economists. For instance, the Phillips curve started life as a simple observed trade-off between unemployment and inflation. But as the theory caught up with the evidence, the Phillips curve emerged as the most important relationship in the way economists viewed the supply-side of the economy and is embedded in all the key macroeconomic models driving policy today.

Another relationship of interest to economists is that between output and unemployment. In 1962, Arthur Okun noted two empirical relationships

- quarterly changes in the unemployment rate were related to quarterly growth in real gross domestic product (GDP)

- deviations in the unemployment rate were related to deviations in GDP from its potential

These have come to be known as the difference and gaps versions of Okun's Law.

Over the years, Okun's Law has been predominantly used as a rule of thumb to predict how changes in output will feed through to the labour market. Conventional wisdom said 'that for every 2 per cent drop in real gross domestic product (GDP) below trend leads to a 1 percentage point rise in the unemployment rate'. However, this relationship has proved to be unstable over time. But whilst the breakdown in the Phillips curve during the stagflation of the 1970s lead to the development of its theoretical underpinning, the same did not happen for Okun's Law.

Simply put, Okun's Law is regarded as a statistical relationship rather than a structural feature of the economy. And like any type of statistical relationship it can be subject to structural breaks or 
regime shift. For instance, structural changes in the labour market leading to shifts in the nonaccelerating inflation rate of unemployment (NAIRU) are considered to change the equilibrium level of unemployment and alter the inflation-output trade-off. Although these supply-side shocks are increasingly integrated into economic theory, structural breaks in the relationship between output and unemployment limited the use of Okun's Law as a forecasting rule and interest waned.

However, there is nothing like a recession to reawaken interest in the relationship between output movements and the unemployment rate - especially due to the severity of the recent downturn in the UK and across most of the world's advanced and emerging market economies. These worries continue into the period of economic recovery. In past UK recessions unemployment has continued to rise even as the economy returns to growth. The last two US recessions have both lead to 'jobless recoveries'. Here, unemployment is likely to be the key issue driving the economic and political landscape for the foreseeable future. So in many ways, the relationship between output and unemployment is as much of key interest today as ever before.

This article looks at various aspects of Okun's Law. Firstly the difference and gap versions are applied to the UK and the stability of the relationship between output and unemployment movements investigated over time. Next of all, differences in the relationship between male and female unemployment and that of different age cohorts in the UK is analysed along with crosscountry comparisons. The final section accepts that the relationship between output and unemployment is more complex than implied by Okun's Law. The production function approach also looks at the impact of other factors such as productivity, participation and activity rates and population growth on the relationship between the two variables.

\section{Output and unemployment in the UK}

\section{Difference version of Okun's Law}

Figure 1 is a scatter plot of quarterly changes in the unemployment rate and growth in GDP between 1973 Q1 and 2010 Q3. This shows reasonable evidence of an inverse relationship between the two variables.

The difference version of Okun's Law is based on the following regression which captures the contemporaneous correlation between output growth and movements in the unemployment rate.

Change in unemployment rate $=a+b^{*}$ real output growth

The results, recorded in Table 1, confirm that the relationship between the two variables is negative and significant. This is also the equation of the regression line shown in Figure 1.

The regression coefficient ( $b=-0.1381$ ) is often referred to as Okun's coefficient and is ordinarily expected to be negative. The ratio -a/b gives the rate of output growth consistent with a stable unemployment rate, or how fast the economy would typically have to grow in order to maintain the existing unemployment rate. In this case $-\mathrm{a} / \mathrm{b}=0.096 /-0.1381=0.7$. Therefore the UK economy 
would ordinarily need to grow at 0.7 per cent each quarter for the unemployment rate to remain constant which is close to its long-term average or trend growth rate.

\section{Table 1 Difference version of Okun's Law}

\begin{tabular}{|c|c|c|c|c|}
\hline \multirow{2}{*}{$\begin{array}{l}\text { Dependent variable: } \\
\text { Sample: }\end{array}$} & \multicolumn{4}{|c|}{ Change in unemployment rate } \\
\hline & $1973 \mathrm{Q} 1$ to $2010 \mathrm{Q3}$ & & & \\
\hline Variable & Coefficient & Standard error & t-statistic & Probability \\
\hline Constant & 0.0961 & 0.0230 & 4.1825 & 0.0000 \\
\hline GDP growth & -0.1381 & 0.0208 & -6.6374 & 0.0000 \\
\hline R-squared & 0.2282 & & & \\
\hline Adjusted R-squared & 0.2230 & & & \\
\hline
\end{tabular}

\section{Figure $1 \quad$ GDP and unemployment in the UK}

Quarterly change in unemployment

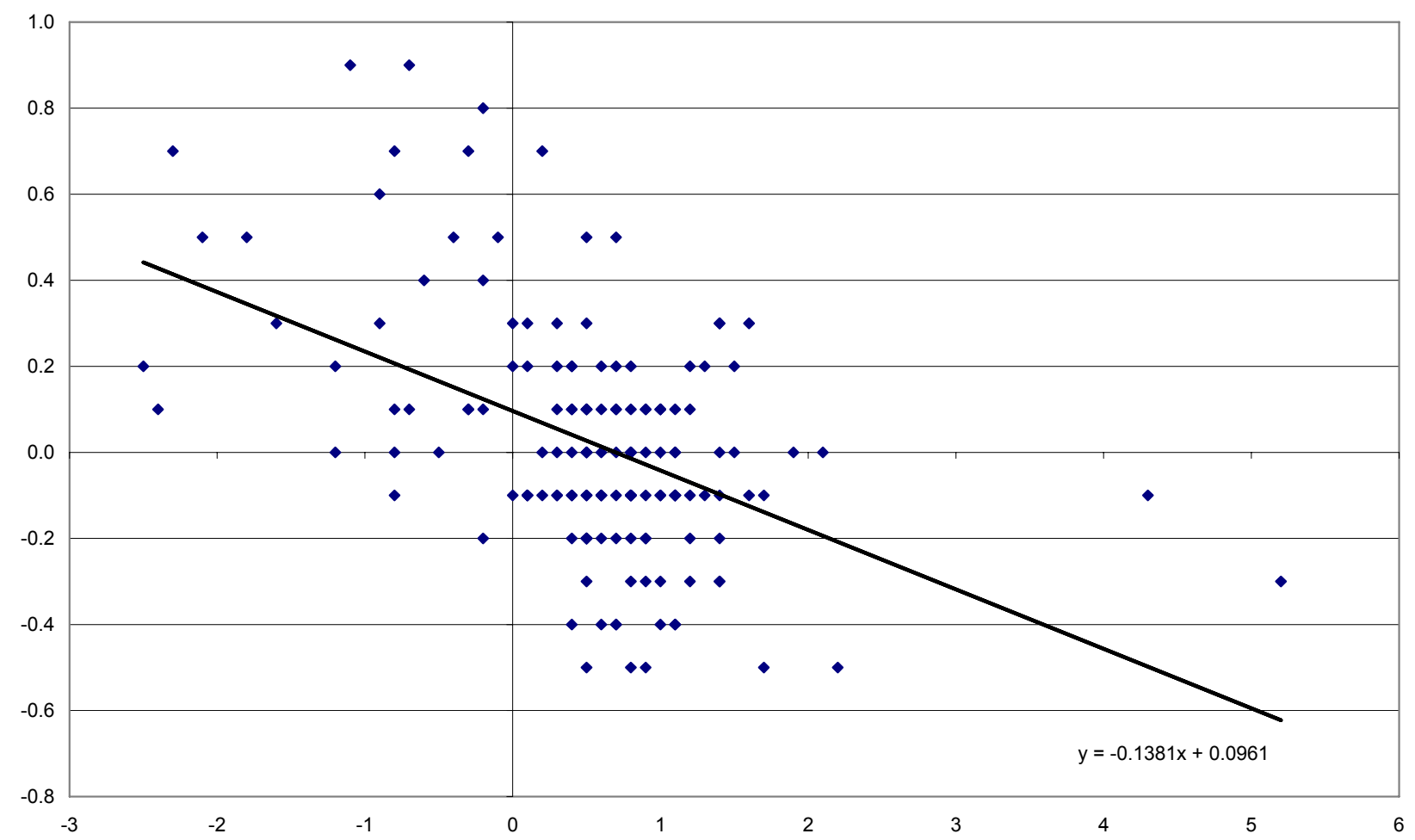

GDP: Quarterly growth rate

Note: Dummying out the two outliers in 1973 Q1 and 1979 Q2 only marginally changes the slope of the regression equation, and both dummies are found to be insignificant at the $5 \%$ level. 


\section{Gap version of Okun's Law}

This version of the law connects changes in the unemployment rate to the gap between actual output and trend or potential output. So if output falls below potential, opening up a negative output gap, unemployment would be expected to an increase. Vice-versa, when actual output is above trend or potential and a positive output gap emerges unemployment is expected to fall. Like the difference version of the law, this emphasises the importance of the economic cycle in determining changes in unemployment, but recognises that trend growth may not be stable over time. In terms of a regression model something like the following would typically be estimated:

Unemployment rate $=\mathrm{a}+\mathrm{b}^{\star}($ gap between potential output and actual output $)$

However, there is not a universal definition of what constitutes 'trend' or 'potential' output, but it is usually thought to be the level of output once cyclical and idiosyncratic measures have been removed. In this sense it is an equilibrium level of output where the economy can grow without experiencing inflationary or deflationary pressures. Another way of putting this is to define trend output as that level of output consistent with unemployment being at its NAIRU. When output rises above trend unemployment falls below its NAIRU and vice-versa.

Trend output though is not a directly observable macroeconomic statistic and any construction of it requires judgement. Here, an estimated trend is calculated using a Hodrick-Prescott (HP) filter, although many other forms of statistical filter or economic method could be viably used. Most trends work on the basis of smoothing out the short-run (cyclical and idiosyncratic) innovations in the data by essentially using a moving average approach. It is important that this is centred, so that the trend estimate for a particular quarter is averaged over preceding and proceedings observations. If not, and based only on past observations, trend movements will lag the actual data - a problem known as phase shifting. For the most part this is not a problem, but towards the end of the sample there are an insufficient number of forward observations to fit a reliable trend. Usual practise is to forecast the series forward in order to provide sufficient observations, and here this has been done by using the GDP forecasts recently published by the Office for Budget Responsibility (OBR).

There are two main ways in which the gaps version of Okun's Law may differ from the trend version.

First, periods of falling output and below trend output are unlikely to coincide exactly. This is because output is likely to fall towards trend at the beginning of a downturn, so negative growth is experienced before below trend output. Also, in the early stages of a recovery, output is likely to be growing towards trend, so GDP growth will become positive before output is above trend.

Second, trend estimates in output are affected by supply-side factors. Therefore it is possible for output to be above trend even if actual output is falling if trend output happens to be falling even faster.

For the most part these factors will mainly result in temporal differences between the two approaches but this cannot be taken for granted. 
Regression results are presented in the first panel of Table $\mathbf{2}$ showing a significantly negative relationship between the output gap and changes in unemployment. Note though that R-squared is slightly lower than compared with the difference version in Table 1 indicating a slightly poorer fit.

This may be because of an asymmetry in the way unemployment and output is treated in the basic gap version of Okun's Law. Trend output is allowed to change over time but not trend unemployment, even though the two are arguably related through the NAIRU. Therefore a modified version of the gap model is to estimate

Unemployment gap $=b^{*}$ output gap

Where the unemployment gap is the difference between the actual unemployment rate and an estimate of the NAIRU. Like potential output, NAIRU is not a directly observable time series and an estimate has been constructed using a HP filter and forecasts published by the OBR in order to provide sufficient end of sample observations. As the dependent variable is different it is incorrect to use R-squared to compare good of fit, but the results presented in the second panel of Table 2 show the alternative model does fit fairly well.

\section{Table $2 \quad$ Gap versions of Okun's Law}

\begin{tabular}{|c|c|c|c|c|}
\hline \multirow{2}{*}{$\begin{array}{l}\text { Dependent variable: } \\
\text { Sample: }\end{array}$} & \multicolumn{4}{|c|}{ Change in unemployment rate } \\
\hline & 1973 Q1 to 2010 Q3 & & & \\
\hline Variable & Coefficient & Standard error & t-statistic & Probability \\
\hline Constant & 0.0270 & 0.0211 & 1.2839 & 0.2012 \\
\hline Output gap & -0.0685 & 0.0128 & -5.3340 & 0.0000 \\
\hline R-squared & 0.1603 & & & \\
\hline Adjusted R-squared & 0.1547 & & & \\
\hline
\end{tabular}

\begin{tabular}{|c|c|c|c|c|}
\hline Dependent variable: & Unemployment gap & & & \\
\hline Sample: & 1973 Q1 to 2010 Q3 & & & \\
\hline Variable & Coefficient & Standard error & t-statistic & Probability \\
\hline Output gap & -0.2851 & 0.0225 & -12.6911 & 0.0000 \\
\hline R-squared & 0.5174 & & & \\
\hline Adjusted R-squared & 0.5174 & & & \\
\hline
\end{tabular}


The statistically significant and inverse relation between the unemployment gap and the output gap is plain to see in Figure 2 where both estimates are plotted. This emphasises the importance of cyclical movements in driving changes in the unemployment rate, but also that longer run changes in the trend growth rate of the economy and the equilibrium rate of unemployment are also important factors.

\section{Figure 2 Gap ${ }^{1}$ version of Okun's Law}

Per cent

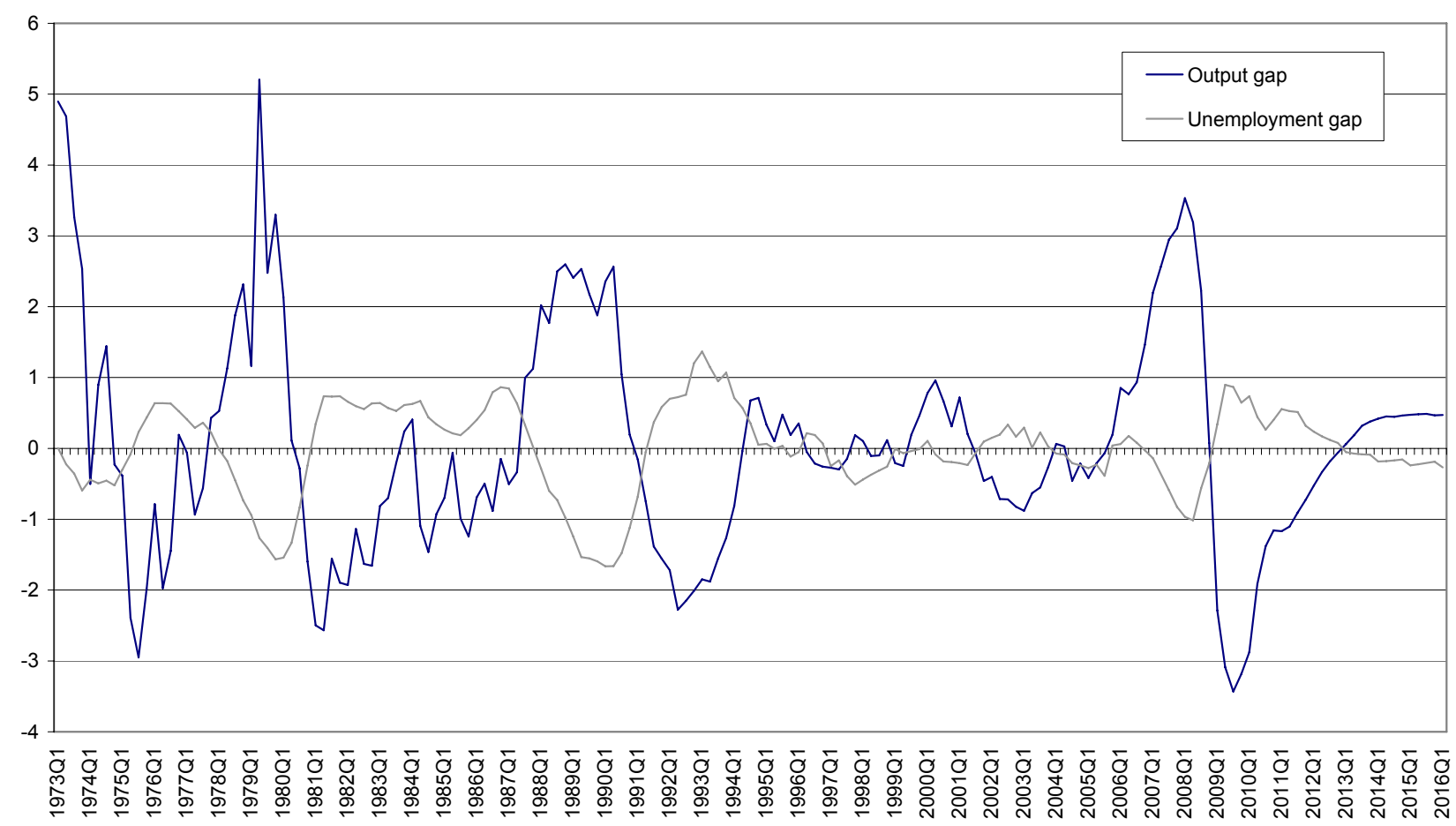

1. The output gap is expressed as a percentage of GDP, whereas the unemployment gap is expressed as a percentage point difference from the NAIRU. The estimates extent to 2016 Q1 by making use of OBR forecasts.

\section{Dynamic versions of Okun's law}

The difference and gaps versions of Okun's Law shown in Tables 1 and 2 reflect the contemporaneous relationship between GDP and the labour market - that is the immediate impact of the economic cycle on the unemployment rate. In reality, the relationship between the two, specifically the pass through from output to unemployment, is unlikely to be contemporaneous and more gradual.

It is generally assumed that firms face costs in changing the size of their workforce. These hiring and firing costs reflect the severance costs of making workers redundant; and the search, recruitment and training costs of hiring new workers. There are also secondary, more indirect costs. Making workers redundant could impact on the morale of the existing workforce, and the firm will lose any firm-specific skills inherent in those workers which would need to be replaced if 
the firm decided to hire again. Hiring new workers also creates extra liability should the workforce need to be cut at some point in the future. Hiring and firing costs therefore create rigidities and inertias that prevent the rapid pass through of output changes to unemployment.

These are likely to be compounded by the degree of uncertainty over the economic outlook faced by firms who will not know for sure the size and duration of output movements in any direction. A rational response would be a 'wait and see' approach, where firms adjust their workforces gradually whilst expectations are formed adaptively about the true state of the economy. These extra dynamics can be estimated by adding lags of GDP growth to the right hand side of the difference version. As shown in the first panel in Table 3, not only the contemporaneous change in GDP is significant, but also four lags. A notable improvement to the goodness of fit over the basic difference version estimated in Table 1 is shown by the improvement in adjusted R-squared from 0.22 to 0.53 .

Adding lags of the change in the unemployment rate to the right hand side of the equation may also add more information. This suggests that the recent history of unemployment matters as a determinant of current unemployment - reflecting the importance of rigidities and inertia in the labour market in leading to a gradual adjustment in the unemployment rate to output movements. Linking current unemployment to past unemployment may also reflect persistent changes in unemployment (often known as hysteresis) that are related to changes in the equilibrium unemployment rate or NAIRU.

In the second panel of Table 3, lags of unemployment changes are found to be positive and significant, implying that unemployment usually moves in the same direction as past changes. The goodness of fit of the equation is also improved as adjusted R-squared rises to 0.67 , implying that both cyclical and structural factors are key drivers of the unemployment rate.

\section{Table 3 Dynamic versions of Okun's Law}

\begin{tabular}{|c|c|c|c|c|}
\hline \multirow{2}{*}{$\begin{array}{l}\text { Dependent variable: } \\
\text { Sample: }\end{array}$} & \multicolumn{4}{|c|}{ Change in unemployment rate } \\
\hline & 1973 Q1 to 2010 Q3 & & & \\
\hline Variable & Coefficient & Standard error & t-statistic & Probability \\
\hline Constant & 0.2163 & 0.0216 & 9.9935 & 0.0000 \\
\hline GDP growth & -0.0990 & 0.0170 & -5.8153 & 0.0000 \\
\hline GDP growth $(-1)$ & -0.0874 & 0.0170 & -5.1477 & 0.0000 \\
\hline GDP growth (-2) & -0.0833 & 0.0167 & -4.9788 & 0.0000 \\
\hline GDP growth $(-3)$ & -0.0511 & 0.0167 & -3.0549 & 0.0027 \\
\hline GDP growth (-4) & -0.0420 & 0.0167 & -2.5178 & 0.0129 \\
\hline R-squared & 0.5493 & & & \\
\hline Adjusted R-squared & 0.5337 & & & \\
\hline
\end{tabular}




\begin{tabular}{|c|c|c|c|c|}
\hline \multirow{2}{*}{$\begin{array}{l}\text { Dependent variable: } \\
\text { Sample: }\end{array}$} & \multicolumn{4}{|c|}{ Change in unemployment rate } \\
\hline & 1973 Q1 to 2010 Q3 & & & \\
\hline Variable & Coefficient & Standard error & t-statistic & Probability \\
\hline Constant & 0.0738 & 0.0176 & 4.2043 & 0.0000 \\
\hline GDP growth & -0.0784 & 0.0142 & -5.5121 & 0.0000 \\
\hline GDP growth (-1) & -0.0462 & 0.0155 & -2.9930 & 0.0032 \\
\hline Change in unemployment rate $(-1)$ & 0.4048 & 0.0789 & 5.1275 & 0.0000 \\
\hline Change in unemployment rate $(-2)$ & 0.2526 & 0.0717 & 3.5218 & 0.0006 \\
\hline R-squared & 0.6793 & & & \\
\hline Adjusted R-squared & 0.6705 & & & \\
\hline
\end{tabular}

\section{Has Okun's Law been stable over time?}

A long time series of economic data is likely to include a number of structural breaks. These would be expected to lead to fundamental changes in the relationship between variables and estimating a simple regression model, as in Table 1, would average over all of these shifts. Extended versions of the difference and gap versions of Okun's Law suggest both cyclical and structural factors are important determinants of the unemployment rate.

The structural stability of Okun's Law can be assessed by using rolling regressions. These breakdown the sample into overlapping windows of a given period and by estimating the difference version of the law in each it is possible to see how the coefficients change over time. Judgements need to be made on the size of these windows. The smaller the observation window the more quickly structural instability in the regression coefficients will be detected, but the lower number of degrees of freedom compromises the power of the tests.

Figure 3 shows how the constant and regressor (Okun's) coefficients change in a rolling 20 quarter sample between 1973 Q1 and 2010 Q3. Analysis based on 20 quarters of data is chosen to more speedily capture cyclical changes in the regression coefficients and it is clear that the constant and Okun's coefficients tend to be much stronger in periods in and around recessions. These include the early 1980s, early 1990s and the most recent downturn in 2008-09.

Table 4 looks at various aspects of the change in unemployment during the last four UK recessions. The first panel in the table shows the rise in the unemployment rate relative to the peak to trough fall in output, and Okun's coefficient here describes the ratio of the two - that is the percentage point rise in the unemployment rate given each per cent drop in GDP. 


\section{Figure 3 Rolling regressions of Okun's Law ${ }^{1}$}

Coefficient values

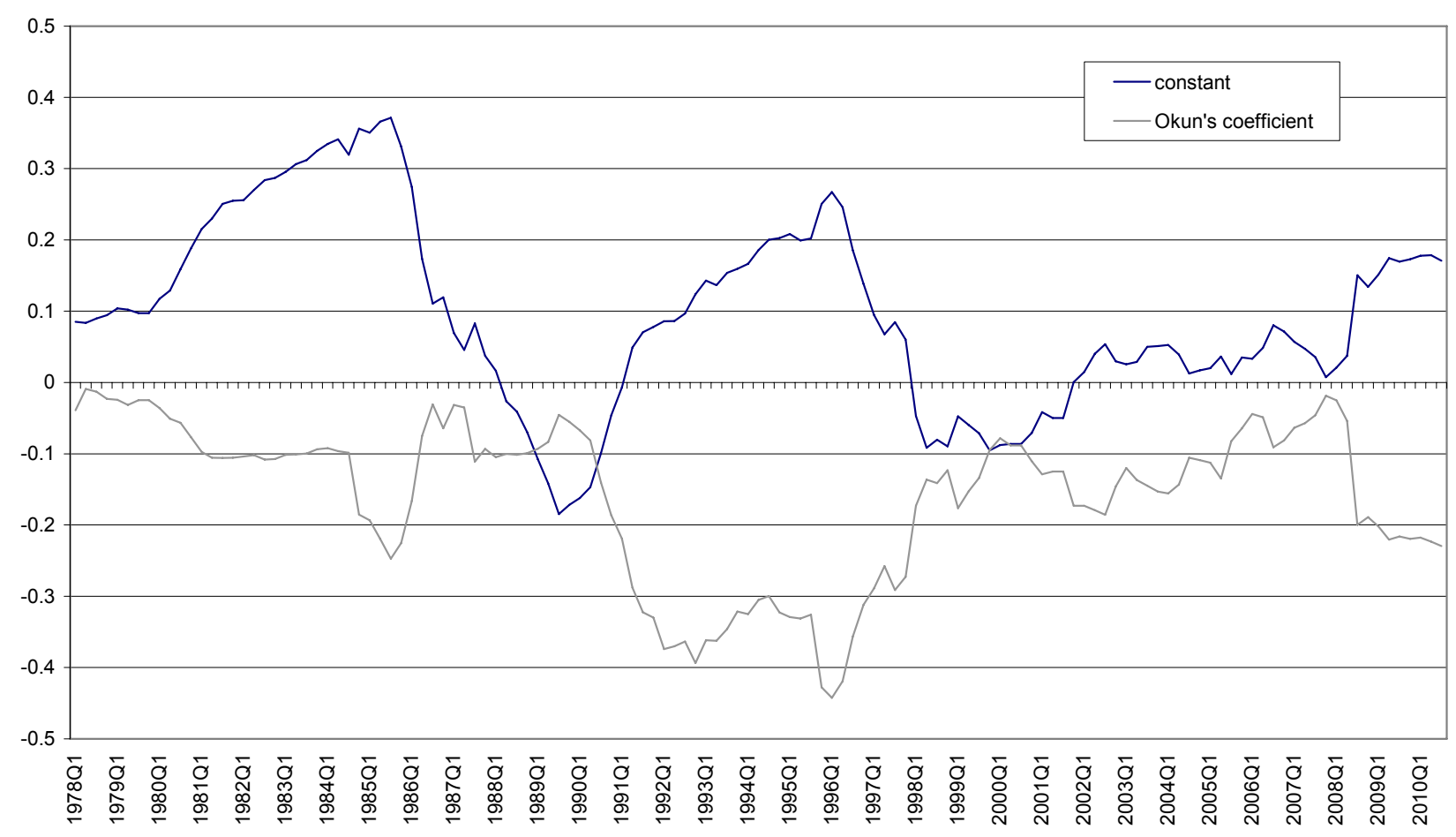

1. Based on a 20 quarter window.

\section{Table $4 \quad$ Okun's Law and recessions}

\begin{tabular}{lccc}
\hline Peak to trough (GDP) & Fall in output (per cent) & $\begin{array}{c}\text { Rise in the unemployment rate } \\
\text { (percentage points) }\end{array}$ & Okun's coefficient \\
\hline 1973 Q2 to 1975 Q3 (R1) & -2.5 & 1 & -0.40 \\
1979 Q2 to 1981 Q1 (R2) & -5.9 & 3.6 & -0.61 \\
1990 Q2 to 1992 Q2 (R3) & -2.5 & 2.9 & -1.16 \\
2008 Q1 to 2009 Q3 (R4) & -6.5 & 2.7 & -0.42 \\
\hline
\end{tabular}

\begin{tabular}{lccc}
\hline Below trend (GDP) & $\begin{array}{c}\text { Rise in the unemploymentTrough to peak unemployment } \\
\text { rate (percentage points) }\end{array}$ & $\begin{array}{c}\text { Rise in the unemployment rate } \\
\text { (percentage points) }\end{array}$ \\
\hline 1974 Q4 to 1977 Q3 (X1) & 2.0 & 1973 Q4 to 1977 Q3 & 2.3 \\
1980 Q3 to 1987 Q3 (X2) & 3.1 & 1979 Q2 to 1984 Q2 & 6.6 \\
1991 Q1 to 1994 Q2 (X3) & 1.7 & 1990 Q2 to 1993 Q1 & 3.7 \\
2009 Q1 - (X4) & 0.6 & 2008 Q1 to 2010 Q2 & 2.8 \\
\hline
\end{tabular}


This shows a number of differences across recessions, notably that despite the large fall in output in the recent recession, the rise in the unemployment rate was relatively small. During the early 1990s recession the rise in the unemployment rate was broadly similar, but the contraction in GDP was far less. The recession of the early 1980s was closer in terms of the peak to trough fall in output, but the increase in the unemployment rate was more marked.

Differences between the recent and past recessions are also apparent when looking at the second panel showing the total trough to peak rise in the unemployment rate. Whereas in the latest recession, the rise in unemployment stabilised relatively quickly following the fall in output, in each of the two previous recessions unemployment continued to increase further. This second panel also shows the rise in unemployment in the period in which GDP was adjudged to be below trend. Here, the rise in the latest recession also appears smaller than in both the early 1980s and 1990s - although it must be borne in mind that according to OBR estimates output is presently and likely to remain below trend for a little while yet, and combined with the possible impact of the government's fiscal austerity programme further rises in the unemployment rate cannot be ruled out.

This analysis suggests two things. First, the relationship between output and unemployment is stronger around periods of economic turmoil like recessions, when output movements can change abruptly. Second, the relationship also differs from recession to recession - so experiences from past downturns may not necessarily provide a good indication of what will happen now.

Dummy variables can be used to test the impact of recessions on the relationship between output and unemployment. In the first panel in Table 5, the dummies R1, R2, R3 and R4 relate to the peak to trough periods in Table 4 and can be applied to the constant and regressor coefficients in the difference version of Okun's Law to see if recessions have level or proportional effects respectively on the relationship.

These are generally found to be insignificant, apart from the notable exception of R2 and R3 which suggest a level shift in the level of unemployment in the early 1980s and early 1990s recessions. In the second panel of Table 5 the dummies X1, X2, X3 and X4 correspond to the below trend output periods also shown in Table 4. Here there appears to be an impact of the downturn on both the level and slope coefficients in Okun's Law for each recession apart from the latest.

The actual and fitted values from these two regressions are shown in Figure $\mathbf{3}$ and this helps to explain the results reported in Table 4. The second model, based on below trend output rather than peak to trough output falls tends to perform better, and this is mainly because a significant part of the rise in unemployment associated with the early 1980s and 1990s recessions occurred after GDP had stopped falling and began a modest recovery. This model though does not work quite so well for the latest downturn. Unlike previous recessions, the increase in the unemployment rate has strongly coincided with the period in which output fell from peak to trough, and although output is judged by both OBR and the Bank of England to still be below trend, further increases in the unemployment rate are yet to emerge. Of course, this should also be taken as a preliminary conclusion, as both the OBR and Bank of England emphasise the uncertainty over the immediate economic outlook. 


\section{Table $5 \quad$ Recessions and the difference version of Okun's Law}

\begin{tabular}{|c|c|c|c|c|}
\hline \multirow{2}{*}{$\begin{array}{l}\text { Dependent variable: } \\
\text { Sample: }\end{array}$} & \multicolumn{4}{|c|}{ Change in unemployment rate } \\
\hline & 1973 Q1 to 2010 Q3 & & & \\
\hline Variable & Coefficient & Standard error & t-statistic & Probability \\
\hline Constant & -0.0065 & 0.0305 & -0.2148 & 0.8303 \\
\hline GDP growth & -0.0600 & 0.0281 & -2.1354 & 0.0345 \\
\hline $\mathrm{R} 1$ & 0.1079 & 0.0828 & 1.3031 & 0.1947 \\
\hline $\mathrm{R} 2$ & 0.5265 & 0.1146 & 4.5935 & 0.0000 \\
\hline R3 & 0.3773 & 0.1057 & 3.5705 & 0.0005 \\
\hline R4 & 0.2230 & 0.1584 & 1.4073 & 0.1615 \\
\hline R1*GDP growth & 0.0335 & 0.0648 & 0.5175 & 0.6056 \\
\hline R2*GDP growth & 0.0666 & 0.0872 & 0.7634 & 0.4465 \\
\hline $\mathrm{R}^{*}{ }^{*} \mathrm{GDP}$ growth & 0.0855 & 0.1986 & 0.4307 & 0.6673 \\
\hline R4*GDP growth & -0.1491 & 0.1166 & -1.2793 & 0.2029 \\
\hline R-squared & 0.4148 & & & \\
\hline Adjusted R-squared & 0.3774 & & & \\
\hline
\end{tabular}

\begin{tabular}{|c|c|c|c|c|}
\hline \multirow{2}{*}{$\begin{array}{l}\text { Dependent variable: } \\
\text { Sample: }\end{array}$} & \multicolumn{4}{|c|}{ Change in unemployment rate } \\
\hline & 1973 Q1 to 2010 Q3 & & & \\
\hline Variable & Coefficient & Standard error & t-statistic & Probability \\
\hline Constant & 0.0158 & 0.0253 & 0.6261 & 0.5323 \\
\hline GDP growth & -0.1230 & 0.0215 & -5.7290 & 0.0000 \\
\hline $\mathrm{X} 1$ & 0.1492 & 0.0693 & 2.1526 & 0.0331 \\
\hline $\mathrm{X} 2$ & 0.3203 & 0.0603 & 5.3164 & 0.0000 \\
\hline $\mathrm{X} 3$ & 0.3222 & 0.0770 & 4.1831 & 0.0001 \\
\hline $\mathrm{X} 4$ & 0.1569 & 0.2556 & 0.6139 & 0.5403 \\
\hline $\mathrm{X} 1{ }^{\star} \mathrm{GDP}$ growth & 0.1293 & 0.0605 & 2.1377 & 0.0343 \\
\hline $\mathrm{X} 2^{*} \mathrm{GDP}$ growth & -0.1609 & 0.0561 & -2.8673 & 0.0048 \\
\hline $\mathrm{X} 3^{\star} \mathrm{GDP}$ growth & -0.3292 & 0.1113 & -2.9592 & 0.0036 \\
\hline $\mathrm{X} 4^{*} \mathrm{GDP}$ growth & -0.1952 & 0.3290 & -0.5931 & 0.5540 \\
\hline R-squared & 0.4365 & & & \\
\hline Adjusted R-squared & 0.4006 & & & \\
\hline
\end{tabular}




\section{Figure 3 Recessions and changes in the unemployment rate ${ }^{1}$}

Percentage points

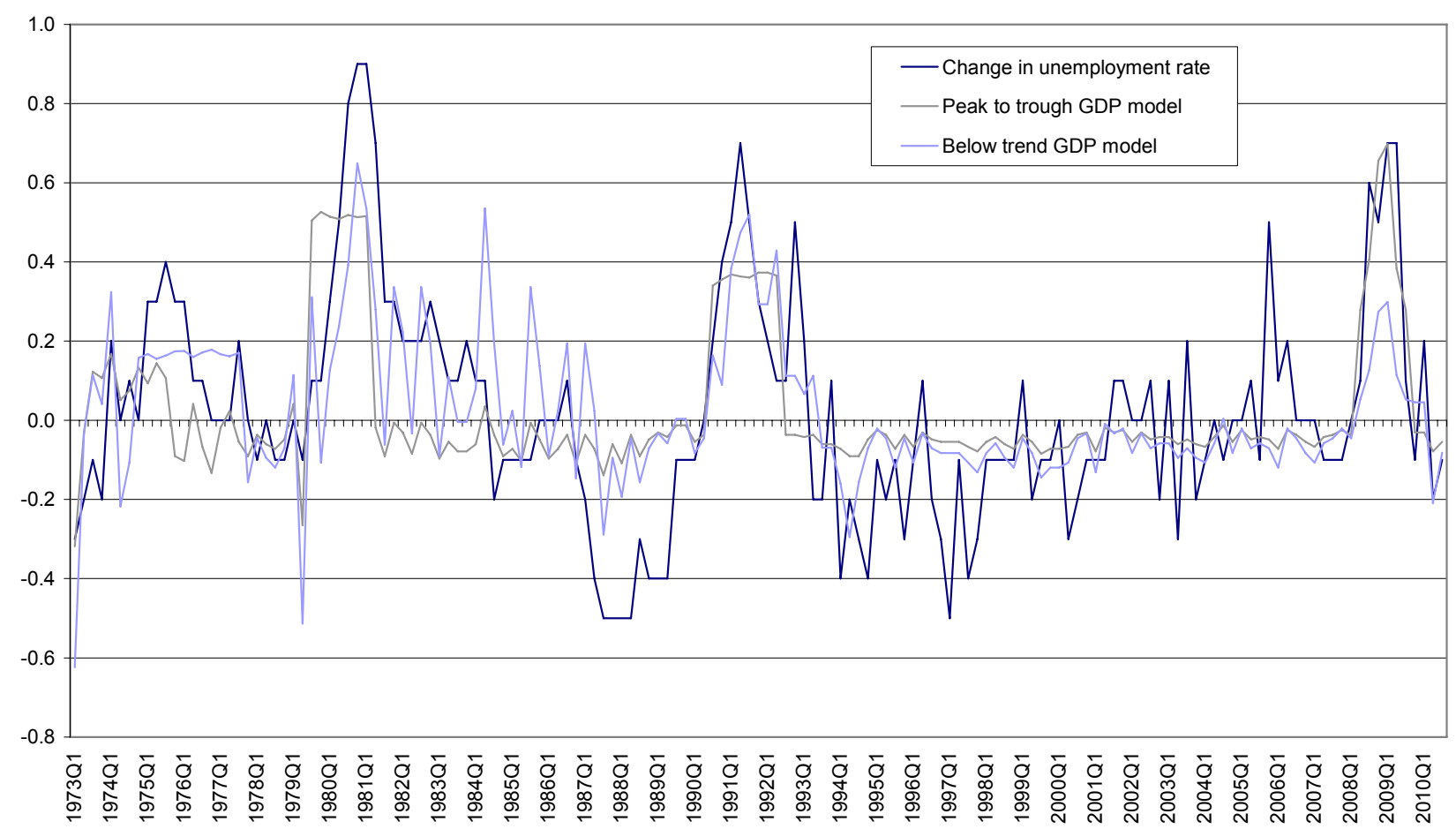

1. Quarterly changes in the actual unemployment rate and the fitted values from the two models reported in Table 5

\section{Okun's Law by gender}

ONS routinely publishes male and female unemployment rates enabling the significance of Okun's Law to be investigated by gender. Figures $\mathbf{4 a}$ and $\mathbf{4 b}$ show scatter graphs, on the same scale, for the difference version of Okun's Law for men and women. The trend lines in each have been estimated, with the respective regression results shown in Table 6. Clearly the negative relationship is stronger for men than women (-0.177 compared to -0.076). Changes in male unemployment are therefore more strongly related to output movements than female unemployment.

This can also be seen in Table 7 which shows the changes in male and female unemployment in the last four recessions. The increase in the unemployment rate for men has been at least double than for women. Okun's coefficient show that in the latest recession, a 1 per cent fall in GDP led to a 0.54 percentage point rise in the male unemployment rate but only a 0.26 percentage point rise in the female unemployment rate. Therefore the economic downturn impacted twice as strongly on male unemployment than female unemployment, a pattern that is also seen in previous recessions. 


\section{Figure $4 a$ Output and male unemployment}

Quarterly change in unemployment

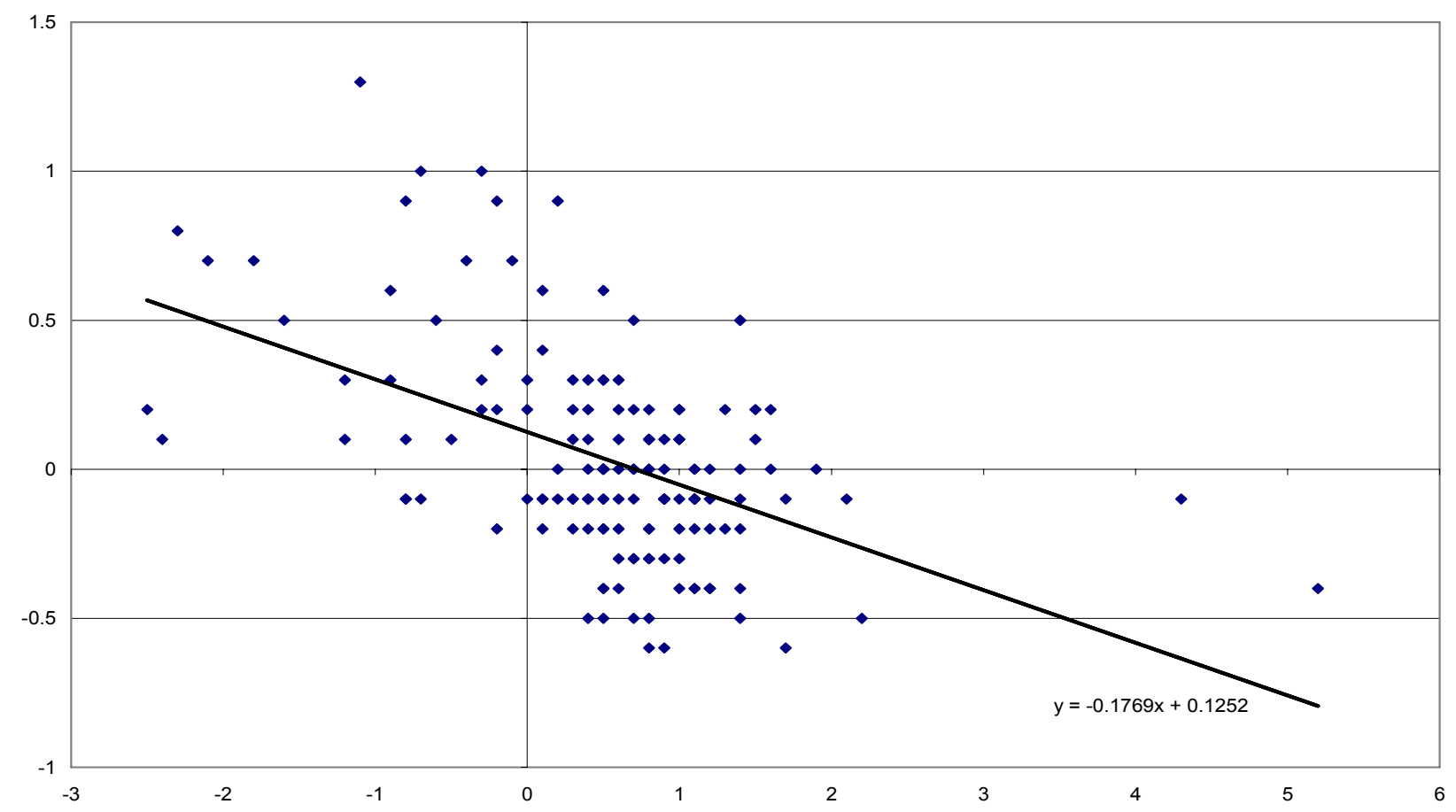

GDP quarter on quarter growth rate

Figure $4 \mathrm{~b} \quad$ Output and female unemployment

Quarterly change in unemployment

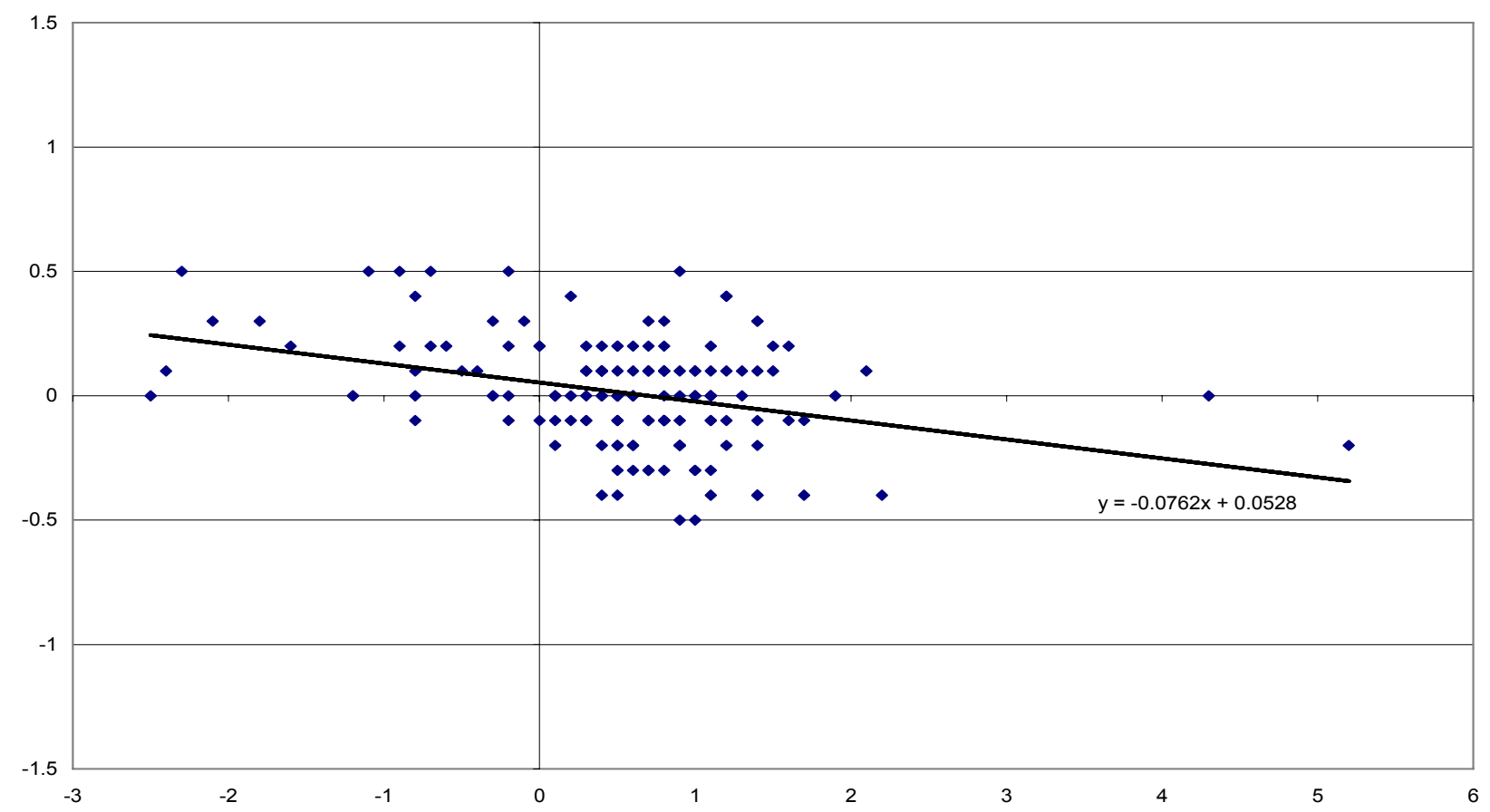

GDP quarter on quarter growth rate 


\section{Table $6 \quad$ Okun's Law by gender}

\begin{tabular}{|c|c|c|c|c|}
\hline \multirow{2}{*}{$\begin{array}{l}\text { Dependent variable: } \\
\text { Sample: }\end{array}$} & \multicolumn{4}{|c|}{ Change in unemployment rate (Men) } \\
\hline & $1973 \mathrm{Q} 1$ to $2010 \mathrm{Q} 3$ & & & \\
\hline Variable & Coefficient & Standard error & t-statistic & Probability \\
\hline Constant & 0.1252 & 0.0284 & 4.4129 & 0.0000 \\
\hline GDP growth & -0.1769 & 0.0257 & -6.8855 & 0.0000 \\
\hline R-squared & 0.2414 & & & \\
\hline Adjusted R-squared & 0.2363 & & & \\
\hline
\end{tabular}

\begin{tabular}{|c|c|c|c|c|}
\hline \multirow{2}{*}{$\begin{array}{l}\text { Dependent variable: } \\
\text { Sample: }\end{array}$} & \multicolumn{4}{|c|}{ Change in unemployment rate (Women) } \\
\hline & 1973 Q1 to 2010 Q3 & & & \\
\hline Variable & Coefficient & Standard error & t-statistic & Probability \\
\hline Constant & 0.0528 & 0.0186 & 2.8363 & 0.0052 \\
\hline GDP growth & -0.0762 & 0.0169 & -4.5191 & 0.0000 \\
\hline R-squared & 0.1205 & & & \\
\hline Adjusted R-squared & 0.1146 & & & \\
\hline
\end{tabular}

\section{Table $7 \quad$ Changes to male and female unemployment rates during} recessions

\begin{tabular}{lccccc}
\hline $\begin{array}{l}\text { Peak to trough } \\
\text { (GDP) }\end{array}$ & $\begin{array}{c}\text { Fall in output (per } \\
\text { cent) }\end{array}$ & $\begin{array}{c}\text { Rise in the male } \\
\text { unemployment rate } \\
\text { (percentage points) }\end{array}$ & $\begin{array}{c}\text { Rise in the female } \\
\text { (percentage points) }\end{array}$ & $\begin{array}{c}\text { Okun's coefficient }{ }^{1} \text { - } \\
\text { men }\end{array}$ & $\begin{array}{c}\text { Okun's coefficient }{ }^{1}- \\
\text { women }\end{array}$ \\
\hline 1973 Q2 to 1975 Q3 & -2.5 & 1.3 & 0.3 & -0.52 & -0.12 \\
1979 Q2 to 1981 Q1 & -5.9 & 4.5 & 2.2 & -0.76 & -0.37 \\
1990 Q2 to 1992 Q2 & -2.5 & 4.4 & 0.9 & -1.76 & -0.36 \\
2008 Q1 to 2009 Q3 & -6.5 & 3.5 & 1.7 & -0.54 & -0.26 \\
\hline
\end{tabular}

1. Here Okun's coefficient describes the percentage point change in the unemployment rate following a one percentage point change in GDP.

These results are most likely due to the different patterns of male and female employment across industries and the respective cyclical movements in the output of each. In short, unemployment by gender acts as a proxy for unemployment by industry. Manufacturing and construction, where 
output tends to exhibit particularly strong cyclical movements, also happen to have very high concentrations of male employment. Furthermore, employment in these industries consists of relatively high numbers of temporary and contractual workers, who are easier to dispose of when demand falters. On the other hand, female employment tends to be more strongly concentrated in the public services, especially in areas such as education and health services where employment is far more stable. As a result, recessions tend to hit female unemployment less hard - although if the government's fiscal austerity programme leads to public sector job reductions this may fall more significantly on women.

Female inactivity rates have fallen markedly in the last two decades, but rates are still higher than for men. Although no evidence is presented in this article, it is a reasonable assumption that female workers are more likely to move into and out of inactivity, also cushioning the impact of the cycle on unemployment.

\section{Okun's Law by age}

The rise and fall in GDP over the last decade and a half also seems to have impacted differently on the unemployment rates of different age groups. Unemployment rates by age are only available from 1992 onwards which slightly limits the analysis as only one recession is included, but Table 8 shows how unemployment rates by age changed during the period of 'Great Moderation' (1993 Q1 to 2008 Q1) and the following recession (2008 Q1 to 2010 Q1).

There does not appear to be an age-related pattern regarding the fall in unemployment rates during the sustained period of economic growth between 1993 and 2008. However, the increase in unemployment rates in the recent downturn is clearly inversely related to age - impacting the strongest on the younger cohorts and the least on the older cohorts. These results are confirmed when looking at the difference version of Okun's Law for the six age cohorts which are presented in Table 9 and summarised in Figure 5. Over the sample in question, cyclical changes in output have affected the unemployment rates of younger age groups by more than older age groups.

The disproportionate impact of the recent recession on the unemployment of younger people has been widely reported. The smaller rise in unemployment rates during the recession may have resulted from labour hoarding - reducing the need for firms to make new hires. The uncertain economic outlook would also reduce the willingness of firms to take on new workers. A sharp reduction in job vacancies and the suspension of graduate recruitment schemes would undoubtedly hit younger people the hardest.

\section{Table $8 \quad$ Percentage point changes in unemployment rates by age}

\begin{tabular}{lccccccc}
\hline & $\mathbf{1 6}$ to $\mathbf{1 7}$ & $\mathbf{1 8}$ to $\mathbf{2 4}$ & $\mathbf{2 5}$ to $\mathbf{3 4}$ & $\mathbf{3 5}$ to $\mathbf{4 9}$ & $\mathbf{5 0}$ to $\mathbf{6 4}$ & $\mathbf{6 5}$ and over & All \\
\hline 1993 Q1 to 2008 Q1 & 4.5 & -5.7 & -6.2 & -4.2 & -6.3 & -2.3 & -5.4 \\
2008 Q1 to 2010 Q1 & 11 & 5.7 & 3.5 & 2 & 1.9 & 1.3 & 2.8 \\
\hline
\end{tabular}




\section{Table 9 Testing Okun's Law by age}

\begin{tabular}{|c|c|c|c|c|}
\hline \multirow{2}{*}{$\begin{array}{l}\text { Dependent variable: } \\
\text { Sample: }\end{array}$} & \multicolumn{4}{|c|}{ Change in unemployment rate (16-17 years) } \\
\hline & 1992 Q3 to 2010 Q3 & & & \\
\hline Variable & Coefficient & Standard error & t-statistic & Probability \\
\hline Constant & 0.5541 & 0.1631 & 3.3983 & 0.0011 \\
\hline GDP growth & -0.6265 & 0.1918 & -3.2661 & 0.0017 \\
\hline R-squared & 0.1306 & & & \\
\hline Adjusted R-squared & 0.1184 & & & \\
\hline
\end{tabular}

\begin{tabular}{|c|c|c|c|c|}
\hline \multirow{2}{*}{$\begin{array}{l}\text { Dependent variable: } \\
\text { Sample: }\end{array}$} & \multicolumn{4}{|c|}{ Change in unemployment rate (18-24 years) } \\
\hline & $1992 \mathrm{Q} 3$ to $2010 \mathrm{Q} 3$ & & & \\
\hline Variable & Coefficient & Standard error & t-statistic & Probability \\
\hline Constant & 0.2978 & 0.0668 & 4.4612 & 0.0000 \\
\hline GDP growth & -0.4855 & 0.0785 & -6.1816 & 0.0000 \\
\hline R-squared & 0.3499 & & & \\
\hline Adjusted R-squared & 0.3407 & & & \\
\hline
\end{tabular}

\begin{tabular}{|c|c|c|c|c|}
\hline \multirow{2}{*}{$\begin{array}{l}\text { Dependent variable: } \\
\text { Sample: }\end{array}$} & \multicolumn{4}{|c|}{ Change in unemployment rate (25-34 years) } \\
\hline & $1992 \mathrm{Q} 3$ to $2010 \mathrm{Q} 3$ & & & \\
\hline Variable & Coefficient & Standard error & t-statistic & Probability \\
\hline Constant & 0.1274 & 0.0434 & 2.9378 & 0.0045 \\
\hline GDP growth & -0.2984 & 0.0510 & -5.8478 & 0.0000 \\
\hline R-squared & 0.3251 & & & \\
\hline Adjusted R-squared & 0.3156 & & & \\
\hline
\end{tabular}


Dependent variable:

Sample:

Variable

Constant

GDP growth

R-squared

Adjusted R-squared

Change in unemployment rate (35-49 years)

1992 Q3 to 2010 Q3

\section{Coefficient}

0.0837

$-0.1793$

0.2802

0.2701
Standard error

0.0290

0.0341 t-statistic

2.8885

$-5.2576$
Probability

0.0051

0.0000

\begin{tabular}{|c|c|c|c|c|}
\hline \multirow{2}{*}{$\begin{array}{l}\text { Dependent variable: } \\
\text { Sample: }\end{array}$} & \multicolumn{4}{|c|}{ Change in unemployment rate (50-64 years) } \\
\hline & 1992 Q3 to 2010 Q3 & & & \\
\hline Variable & Coefficient & Standard error & t-statistic & Probability \\
\hline Constant & 0.0672 & 0.0327 & 2.0551 & 0.0436 \\
\hline GDP growth & -0.1982 & 0.0385 & -5.1534 & 0.0000 \\
\hline R-squared & 0.2722 & & & \\
\hline Adjusted R-squared & 0.2620 & & & \\
\hline
\end{tabular}

\begin{tabular}{|c|c|c|c|c|}
\hline \multirow{2}{*}{$\begin{array}{l}\text { Dependent variable: } \\
\text { Sample: }\end{array}$} & \multicolumn{4}{|c|}{ Change in unemployment rate $(65+$ years) } \\
\hline & 1992 Q3 to 2010 Q3 & & & \\
\hline Variable & Coefficient & Standard error & t-statistic & Probability \\
\hline Constant & 0.0308 & 0.0893 & 0.3455 & 0.7307 \\
\hline GDP growth & -0.1015 & 0.1050 & -0.9662 & 0.3372 \\
\hline R-squared & 0.0130 & & & \\
\hline Adjusted R-squared & -0.0009 & & & \\
\hline
\end{tabular}




\section{Figure $5 \quad$ Okun's Law by age - summary ${ }^{1}$}

\section{Percentages}

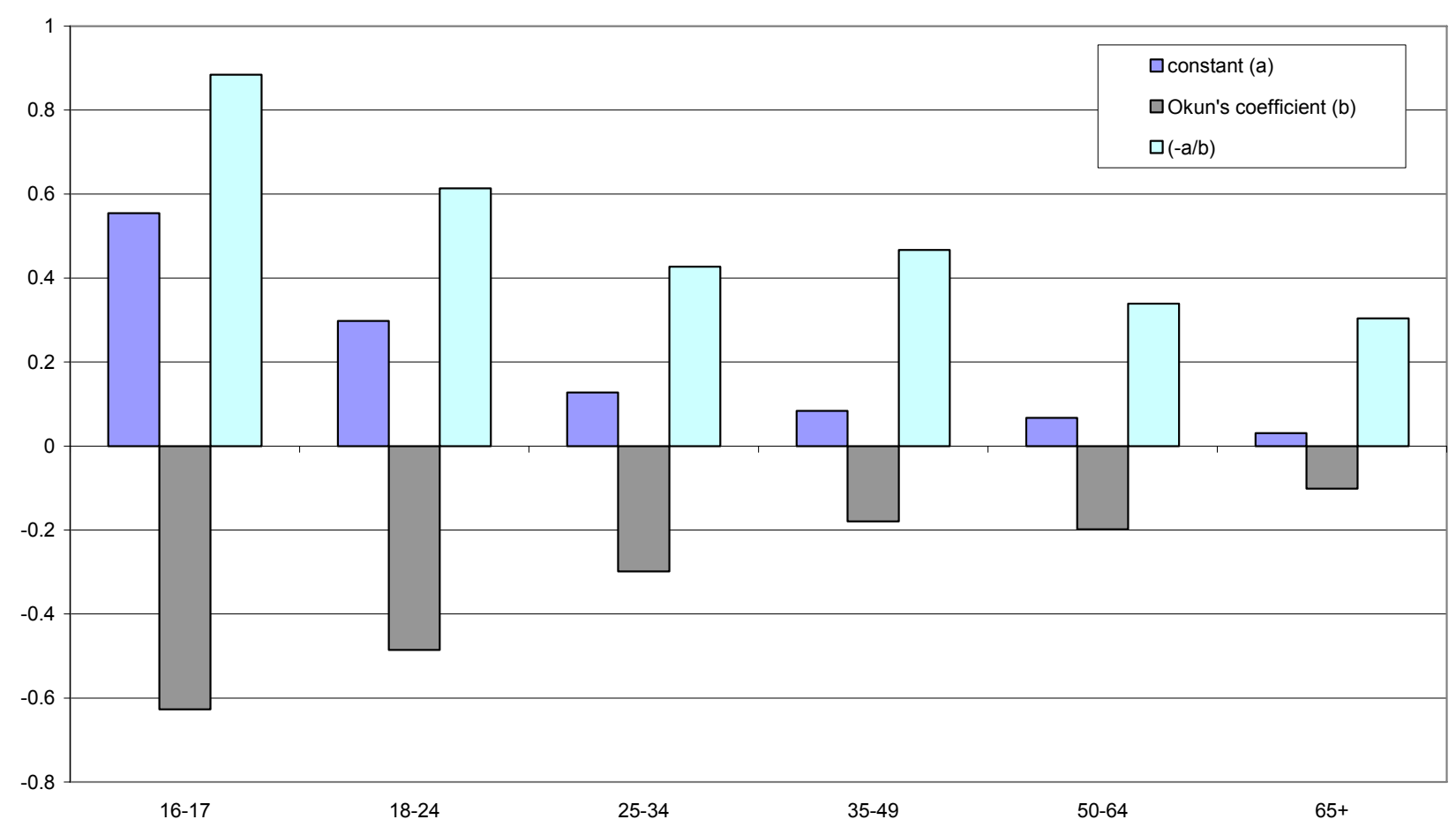

1. Coefficients are taken from the regression results reported in Table 8. (-a/b) gives an indication of how fast the economy needs to grow (in percent, quarter on quarter) to keep the unemployment rate in each age cohort constant. The sample is 1992 Q3 to 20010 Q3.

In contrast, unemployment rates in older age cohorts have exhibited much smaller percentage point increases. For example, between 2008 Q1 and 2010 Q1 the unemployment rates of those aged 50 to 64 and 65 and over increased by 1.9 percentage points and 1.3 percentage points compared to 2.8 percentage points for all , 5.7 percentage points for those aged 18 to 24 and 11 percentage points for those aged 16 to 17 .

There are number of factors that may have reduced the impact of the downturn on older workers including:

- changes to accountancy regulations and deficits in company pension schemes which make it harder to 'pension off' older workers

- older workers increasingly working part time

- older workers can move into inactivity as well as unemployment

\section{Cross-country evidence on Okun's Law}

Quarterly unemployment and GDP data collated by the OECD (Organisation for Economic Cooperation and Development) allows Okun's Law to be evaluated on a cross-section of the major 
advanced economies between 1984 Q1 and 2010 Q3. The full set of regression results are reported in Table 10. The main findings are:

- Okun's coefficient, reflecting the reaction of the unemployment rate to changes in GDP is the lowest for Japan, followed by Italy and Germany

- Next comes France and the UK, with Okun's coefficient being the greatest for the USA

Conventional wisdom is that the cyclical response of unemployment rates is, in part, determined by the relative flexibility of the labour market. Where employment regulation is lower firms have greater ability to alter the size of their workforces in response to changes in demand. Therefore the highly institutionalised Japanese labour market sits at one end of the spectrum, and the deregulated labour market of the US at the other.

\section{Table 10 Testing Okun's Law across different countries}

\begin{tabular}{|c|c|c|c|c|}
\hline \multirow{2}{*}{$\begin{array}{l}\text { Dependent variable: } \\
\text { Sample: }\end{array}$} & \multicolumn{4}{|c|}{ Change in unemployment rate (UK) } \\
\hline & 1984 Q1 to 2010 Q3 & & & \\
\hline Variable & Coefficient & Standard error & t-statistic & Probability \\
\hline Constant & 0.1058 & 0.0256 & 4.1330 & 0.0001 \\
\hline UK GDP growth & -0.2357 & 0.0291 & -8.1070 & 0.0000 \\
\hline R-squared & 0.3850 & & & \\
\hline Adjusted R-squared & 0.3791 & & & \\
\hline
\end{tabular}

\begin{tabular}{|c|c|c|c|c|}
\hline \multirow{2}{*}{$\begin{array}{l}\text { Dependent variable: } \\
\text { Sample: }\end{array}$} & \multicolumn{4}{|c|}{ Change in unemployment rate (Germany) } \\
\hline & 1984 Q1 to 2010 Q3 & & & \\
\hline Variable & Coefficient & Standard error & t-statistic & Probability \\
\hline Constant & 0.0400 & 0.0225 & 1.7774 & 0.0784 \\
\hline Germany GDP growth & -0.1115 & 0.0209 & -5.3242 & 0.0000 \\
\hline R-squared & 0.2126 & & & \\
\hline Adjusted R-squared & 0.2051 & & & \\
\hline
\end{tabular}




\begin{tabular}{|c|c|c|c|c|}
\hline \multirow{2}{*}{$\begin{array}{l}\text { Dependent variable: } \\
\text { Sample: }\end{array}$} & \multicolumn{4}{|c|}{ Change in unemployment rate (France) } \\
\hline & 1984 Q1 to 2010 Q3 & & & \\
\hline Variable & Coefficient & Standard error & t-statistic & Probability \\
\hline Constant & 0.1221 & 0.0248 & 4.9310 & 0.0000 \\
\hline France GDP growth & -0.2240 & 0.0353 & -6.3494 & 0.0000 \\
\hline R-squared & 0.2774 & & & \\
\hline Adjusted R-squared & 0.2705 & & & \\
\hline
\end{tabular}

\begin{tabular}{|c|c|c|c|c|}
\hline \multirow{2}{*}{$\begin{array}{l}\text { Dependent variable: } \\
\text { Sample: }\end{array}$} & \multicolumn{4}{|c|}{ Change in unemployment rate (Italy) } \\
\hline & 1984 Q1 to 2010 Q3 & & & \\
\hline Variable & Coefficient & Standard error & t-statistic & Probability \\
\hline Constant & 0.0259 & 0.0247 & 1.0467 & 0.2977 \\
\hline Italy GDP growth & -0.0605 & 0.0334 & -1.8107 & 0.0730 \\
\hline R-squared & 0.0303 & & & \\
\hline Adjusted R-squared & 0.0210 & & & \\
\hline
\end{tabular}

\begin{tabular}{|c|c|c|c|c|}
\hline \multirow{2}{*}{$\begin{array}{l}\text { Dependent variable: } \\
\text { Sample: }\end{array}$} & \multicolumn{4}{|c|}{ Change in unemployment rate (Japan) } \\
\hline & $1984 \mathrm{Q} 1$ to $2010 \mathrm{Q} 3$ & & & \\
\hline Variable & Coefficient & Standard error & t-statistic & Probability \\
\hline Constant & 0.0386 & 0.0151 & 2.5576 & 0.0120 \\
\hline Japan GDP growth & -0.0300 & 0.0118 & -2.5552 & 0.0120 \\
\hline R-squared & 0.0585 & & & \\
\hline Adjusted R-squared & 0.0496 & & & \\
\hline
\end{tabular}


Dependent variable: Change in unemployment rate (USA)

Sample:

1984 Q1 to 2010 Q3

Variable

Constant

USA GDP growth

R-squared

Adjusted R-squared
0.4696

Coefficient

0.2322

$-0.3183$

0.4645

The relationships between peak to trough falls in output and increases in the unemployment rate during the latest recession are presented in Figure 6. This tends to confirm, as well as being a driver of, the regression results in Table 10. Italy, Japan and Germany, all of which have relatively large manufacturing sectors, experienced relatively large falls in GDP compared to the pick ups in unemployment rates. The smallest increase in unemployment was registered in Germany, where employment subsidies and short-term working arrangements had a significant effect in lessening the rise in unemployment rates.

\section{Figure $6 \quad$ Peak to trough contractions ${ }^{1}$ in GDP and the rise in unemployment rates across countries}

Per cent

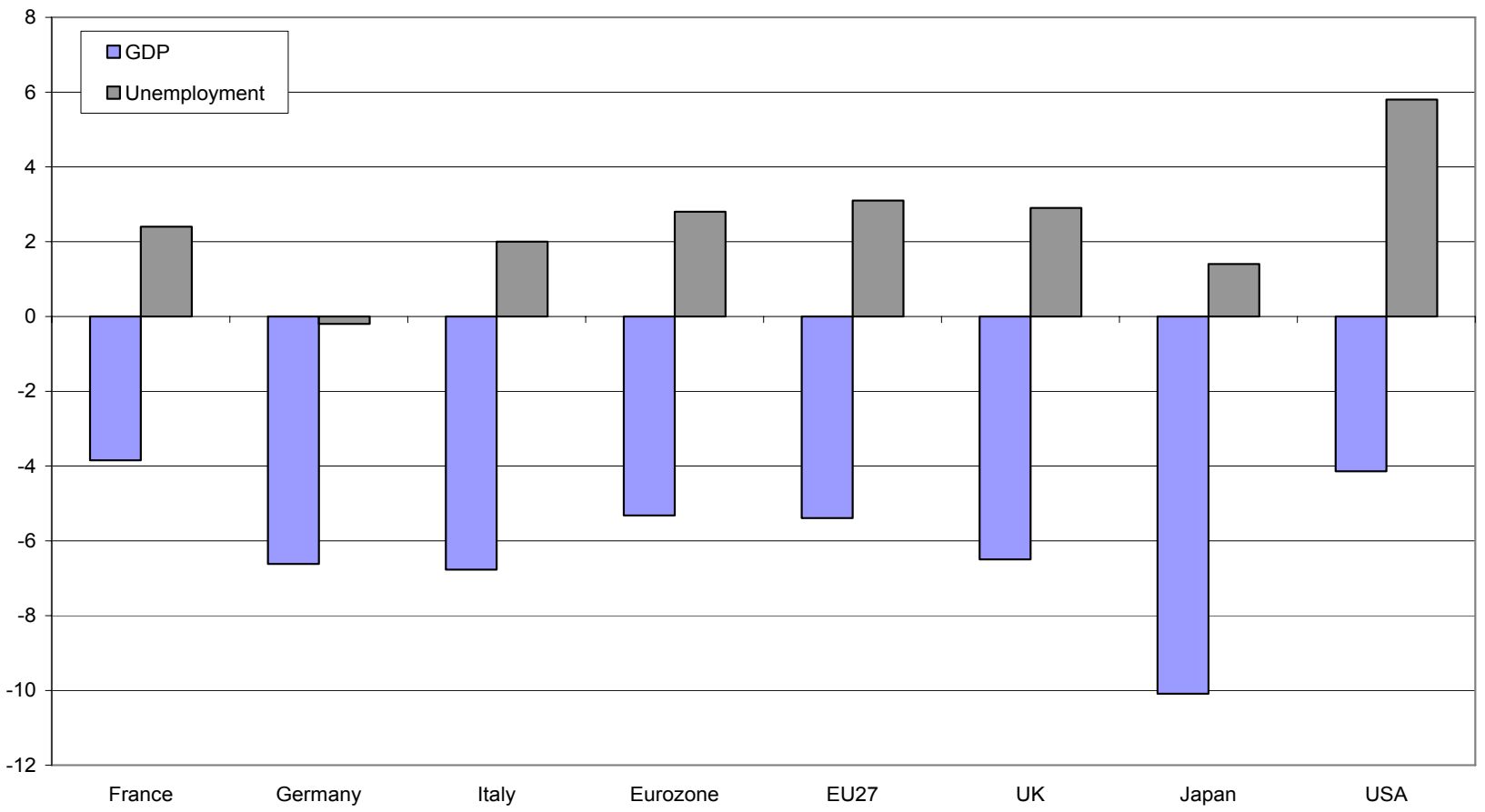

1. The exact timing of the peak to trough contraction in GDP through the recent recession differs slightly from country to country. 
The percentage point increase in UK unemployment was similar to the EU27 and Eurozone country aggregates, despite a sharper fall in GDP and a larger increase in unemployment rates compared to major countries such as Germany, France and Italy. This partly reflects the very large increases in unemployment rates in Ireland and Spain during the recent recession (both over 10 percentage points), which are not shown in Figure 6. In Ireland, a major banking crisis resulted in a sharp contraction in the construction industry and a major fiscal tightening. In Spain, a large proportion of the workforce happened to be on temporary contracts, and therefore highly vulnerable to a contraction in demand.

The USA, despite experiencing a relatively small peak to trough fall in GDP, has suffered from a large increase in its unemployment rate. Furthermore, unemployment has continued to deteriorate even after the economy started to grow again - a problem widely diagnosed as a 'jobless recovery'. Undoubtedly, lower employment regulations make it easier for businesses to shed labour in a downturn, explaining the larger rise in unemployment rates, but the flip side of this is that unemployment should also fall more quickly in the recovery. Historically this has been the case, with US labour market generally rehabilitating itself much faster following a recession than in Europe, where increases in unemployment have been more persistent. However, this is the second successive jobless recovery in the USA, and the stubbornness of unemployment has become both a major economic and political issue.

The main problem appears to be that the strength of the economic recovery is insufficient to persuade firms to start hiring again. Instead, growing output is met from productivity increases, and usually following a recession businesses have available spare capacity in order to achieve this without employing more workers. Uncertainty over the voracity of the economic recovery and low business confidence may also dampen employment intentions - with businesses adopting a cautious approach to how much future capacity may be required in order to meet demand.

\section{Production function approaches}

Okun's original relationship was based on the notion that more labour was required to produce more output of goods and services. Therefore, Okun's position was that the unemployment rate can serve as a useful summary of the amount of labour being used in the economy.

Unemployment in this relationship is used as a proxy for idle resources, and these rise and fall depending on the level of output.

Employment (or lack of it measured in terms of unemployment) though is not the only input into production. The relationship between output and employment, often described by labour productivity, is also influenced by capital inputs and capacity utilisation. Employment inputs themselves are also determined by average working hours, participation rates and the size of the working population. Therefore, it is apparent that changes in output can result from a number of sources and not just limited to the degree of idle labour in the economy. A production function approach recognises this by relating changes in output to a broader array of inputs than just employment (or the part of the labour force that is not unemployed). 
A production function approach allows the breakdown of GDP into a number of contributing factors - for all of which official data is published by ONS.

Output $=$ Output per hour (labour productivity) ${ }^{*}$ Average hours worked * 1-unemployment rate * Activity rate * Household population

Working backwards, the activity rate multiplied by the household population gives the total economically active labour force. Multiplying this by 1-unemployment rate (employment rate) then gives the total level of employment in the economy. Multiplying through by average hours worked gives the total number of hours worked, and finally output per hour then gives the total output of the economy. Therefore changes in output can be decomposed into the contributions resulting from the household population, activity rate, unemployment rate, average hours and output per hour. All of these series can be found in the Labour Market Statistical Bulletin published each month by ONS.

Of course, all of these additional factors may show the same cyclical patterns as the unemployment rate, hence they can be approximated by the unemployment rate and reestablishing the significance of Okun's Law. For instance:

Household population: the Bank of England has suggested that migration flows into the UK, and hence the size of the household population is subject to cyclical influences as short-term migrants seek employment opportunities. It is noted that this has become more significant since the A8 accession of Eastern European economies to the European Union.

Labour force participation rates: may also move around over the cycle reflecting discouraged worker effects. Typically participation will fall in a recession as potential workers realise their prospects are weak and withdraw from the labour market to pursue other goals or through discouragement. Female inactivity rates may also be partly driven by opportunities in the labour market.

Average hours per worker: in recessions, hours worked generally fall as firms cut back on overtime or regular hours in response to lower demand. Reducing worker hours instead of worker numbers would lead to a different dynamic between output and unemployment, especially if larger cuts in hours reduce the need for job shedding.

Labour productivity: one of the key influences here is the rate of labour utilisation - with the intensity at which labour is used varying over the cycle. Productivity though is also driven by other factors such as technology and capital inputs which are harder to measure. Therefore, as is often the case, productivity tends to act as a residual between known inputs and known outputs.

Unless these factors behave in exactly the same way as the unemployment rate the Okun's Law regressions presented in the article thus far will routinely suffer from missing variable bias. 
The easiest way of decomposing output or GDP into these factors is to work in logarithms. In this case, a multiplicative relationship like that expressed here will become log-additive, making it easy to just add up the individual component contributions to output. Furthermore, the log change in a variable approximates a percentage change, so it is also easy to move from contributions to levels to contributions to changes in those levels (growth rates).

Figure 7 shows the relative contributions to quarterly growth in GDP from output per hour, average hours, 1-unemployment rate, activity rate and the household population from 1992 Q2 to 2010 Q3. These dates reflect the period from when the economy started to recover from the recession of the early 1990s up to the present. It is clear that the main contribution to growth over this period has been labour productivity measured in terms of output per hour. It is also clear that during the recent recession a number of these components contributed negatively to GDP growth.

\section{Figure 7 Contributions to output growth, 1992 Q3 to 2010 Q3}

Log change: quarter on quarter

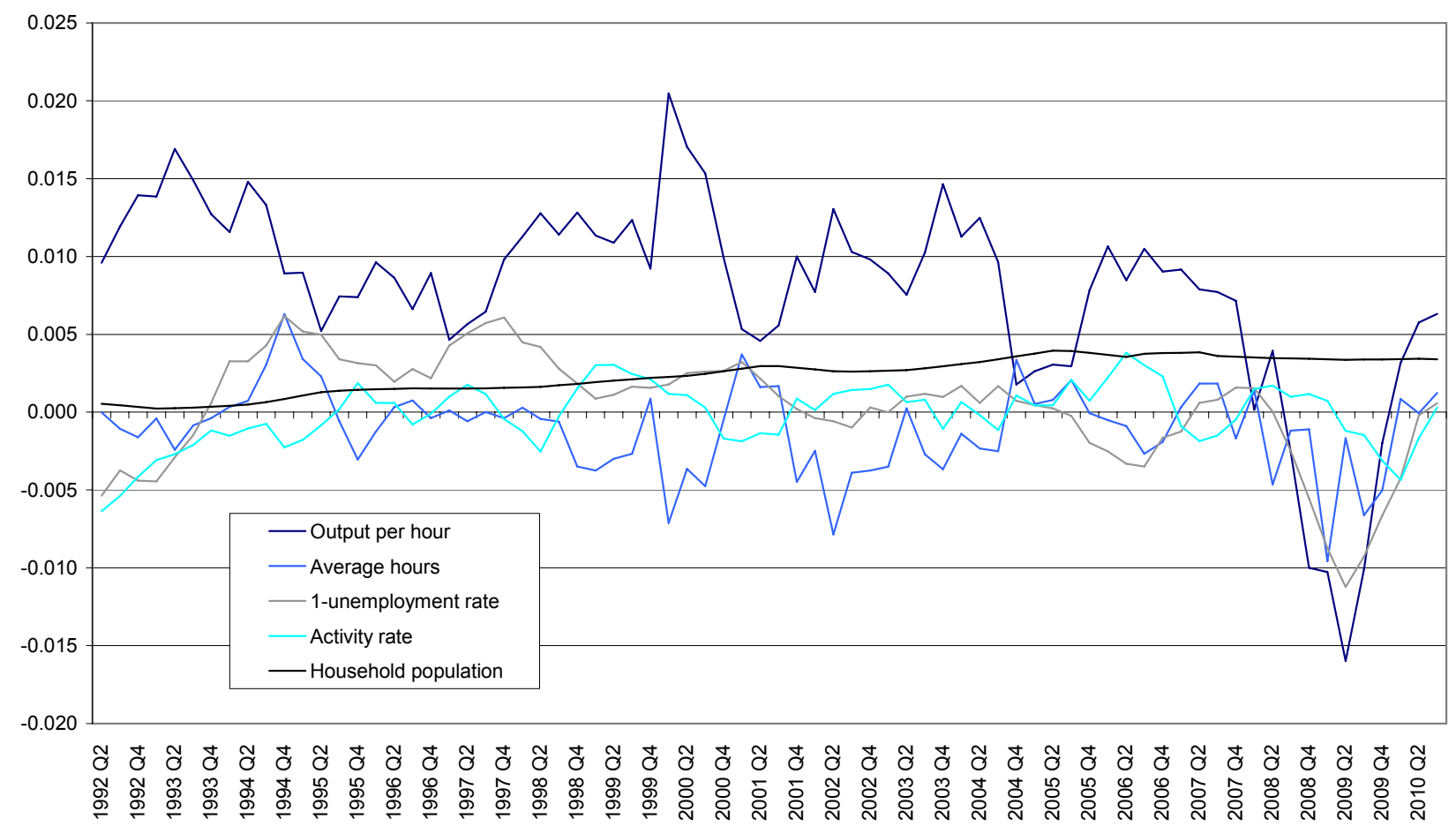

The period from 1992 Q2 to 2008 Q1 heralded the longest unabated economic expansion in the UK economy with 63 successive quarters of growth. Low inflation over this period has meant that it has come to be known as 'The Great Moderation' - reflecting the long continuation of price and output stability. Figure 8 shows the contributions to each of these identified factors to growth during this period - which has also been split into roughly two halves consisting of 1992 Q2 to 2001 Q1 and 2001 Q1 to 2008 Q1. 


\section{Figure $8 \quad$ Contributions to output growth in 'The Great Moderation'}

Log changes over each period

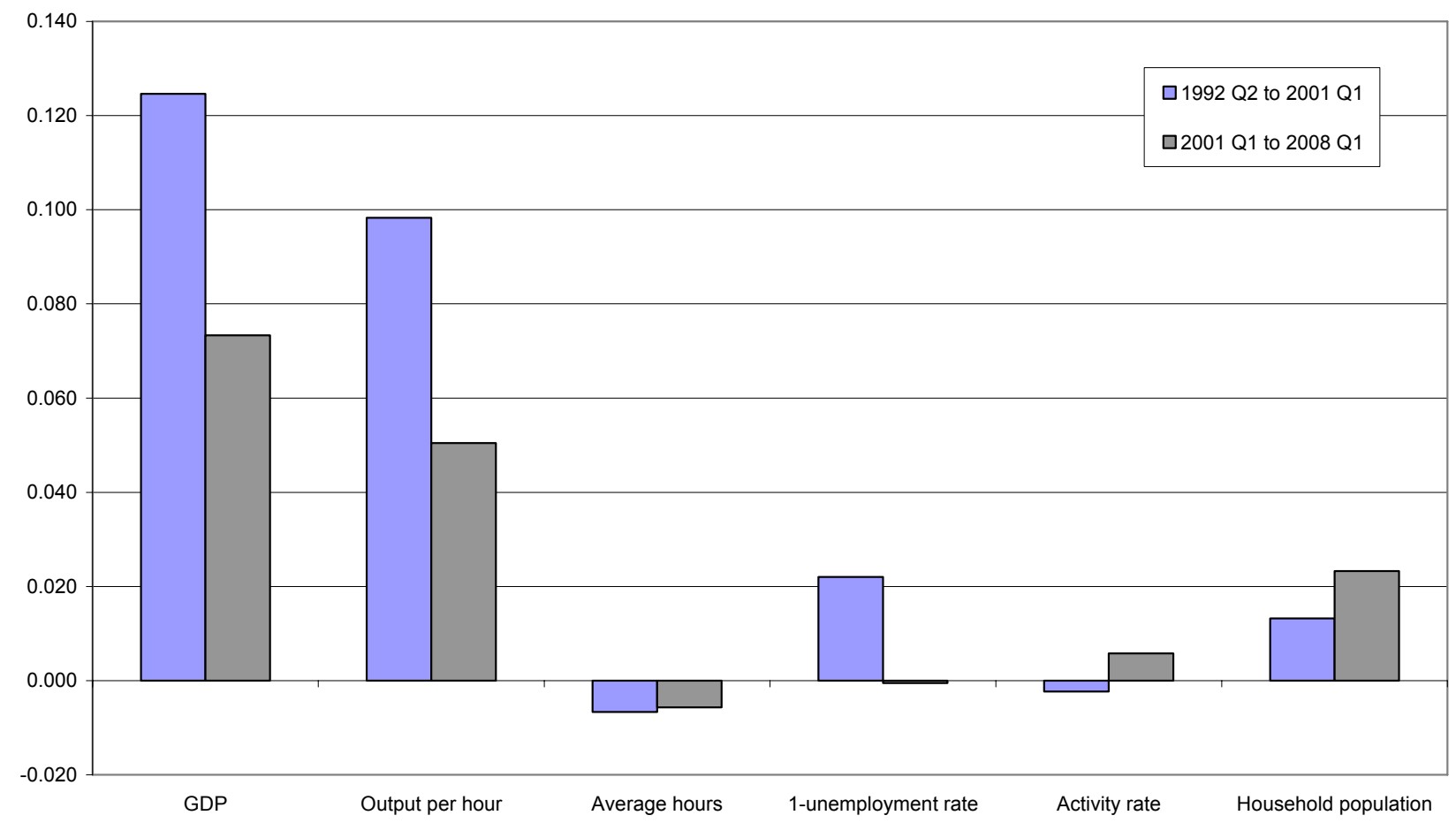

\begin{tabular}{lcccccc}
\hline & GDP & $\begin{array}{c}\text { Output per } \\
\text { hour }\end{array}$ & Average hours & 1-unemployment rate & Activity rate & $\begin{array}{c}\text { Household } \\
\text { population }\end{array}$ \\
\hline 1992 Q2 to 2008 Q1 & 0.198 & 0.149 & -0.012 & 0.022 & 0.003 & 0.036 \\
1992 Q2 to 2001 Q1 & 0.125 & 0.098 & -0.007 & 0.022 & -0.002 & 0.013 \\
2001 Q1 to 2008 Q1 & 0.073 & 0.050 & -0.006 & 0.000 & 0.006 & 0.023 \\
\hline
\end{tabular}

There are two main things to note form Figure 8. First, growth during 'The Great Moderation' was primarily driven by output per hour. Growing inputs also contributed to growth, but the main driver over that period was the efficiency or productivity at which they were used. Average hours made a negative contribution, reflecting a longer term trend to shorter working hours in line with employment legislation and individual preferences. Growth in household population was also fairly important, especially in the second half of the sample and driven predominantly by net inward migration.

Second, growth in the first half of the sample was faster than during the second, accounted for by higher growth in output per hour and a fall in the unemployment rate (increase in the employment rate). This partly reflects that growth in the first half of the sample period includes the recovery period from the previous recession, in which a pick up in capacity utilisation and a fall in unemployment would be expected. It is noticeable though that from 2001 Q1 to 2008 Q1 the contribution of the unemployment (employment) rate was negligible. 
This is very interesting as a preamble, but the main interest in the relationship between unemployment and output is generally centred on periods of economic recession. Therefore Figure 9 shows the contributions to the peak to trough falls in GDP in each of the last three recessions and a number of interesting similarities and differences are evident:

Average hours: it has been widely reported that the increase in unemployment has been relatively small in the latest recession compared to those previously - and one factor accounting for this has been a move to working reduced hours in order to maintain employment levels. Figure 9 disproves this, showing that the negative contribution of falling average hours to growth in the latest recession has not been much different than in previous downturns. In fact, falling average hours were an even more prominent feature of the early 1980s recessions than that recently. This is not altogether unsurprising as the sector of the economy most likely to move to shorter-time working in a downturn are the production industries - which contribute significantly less to total GDP now than they did three decades ago.

Unemployment rate: the actual contribution of an increase in the unemployment rate to the fall in GDP is also fairly similar across recessions. However this is over the period in which the peak to trough fall in output occurred. The latest recession appears to differ somewhat to those of the early 1980 s and early 1990s in that unemployment continued to rise through the early recovery period in the previous two recessions, whereas unemployment appears to have stabilised once output stopped contracting in the more recent downturn.

Output per hour: This plays an important role in explaining the differences between falling output in the last three recessions. The contributions of an increase in the unemployment rate and a fall in average hours are the main contributing factors behind the falling labour input in a downturn. In the early 1980s recession, the contributions of a fall in average hours and an increase in the unemployment rate were slightly greater than in the latest recession, even though the overall peak to trough fall in GDP was lower. As a result, the contribution of falling output per hour has also been greater this time round. Compared to the recession in the early 1990s, the contributions of average hours and the unemployment rate were broadly similar, but the peak to trough fall in output was much greater in the recent recession. Therefore, whilst there was a fairly significant pick up in output per hour in the early 1990s recession, it fell quite considerably in the latest downturn.

Interest in the dynamics between output and unemployment is not only heightened during the period of falling output, but also in the period in which output begins to recover when hope turns to an improvement in the labour market outcomes. At present, GDP is still below its pre-recession (2008 Q1) level, so a complete analysis of the recovery is not yet possible, But Figure 10 shows the relative contributions to the recovery in output from previous recessions and the most recent one so far. 
Figure 9 Contributions to peak to trough output falls in the last three UK recessions

Log changes

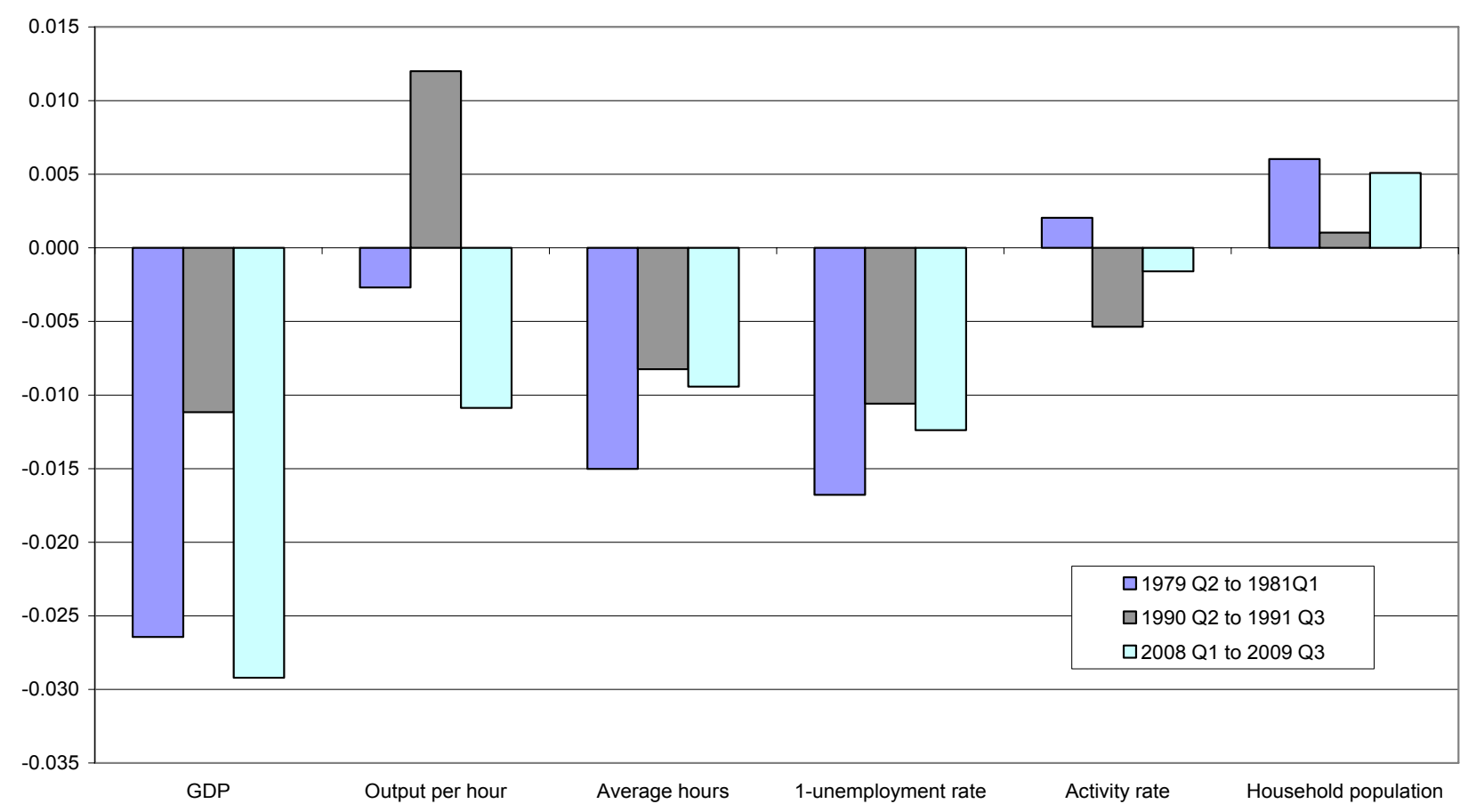

Figure 10 Contributions to the economic recovery from recessions Log changes

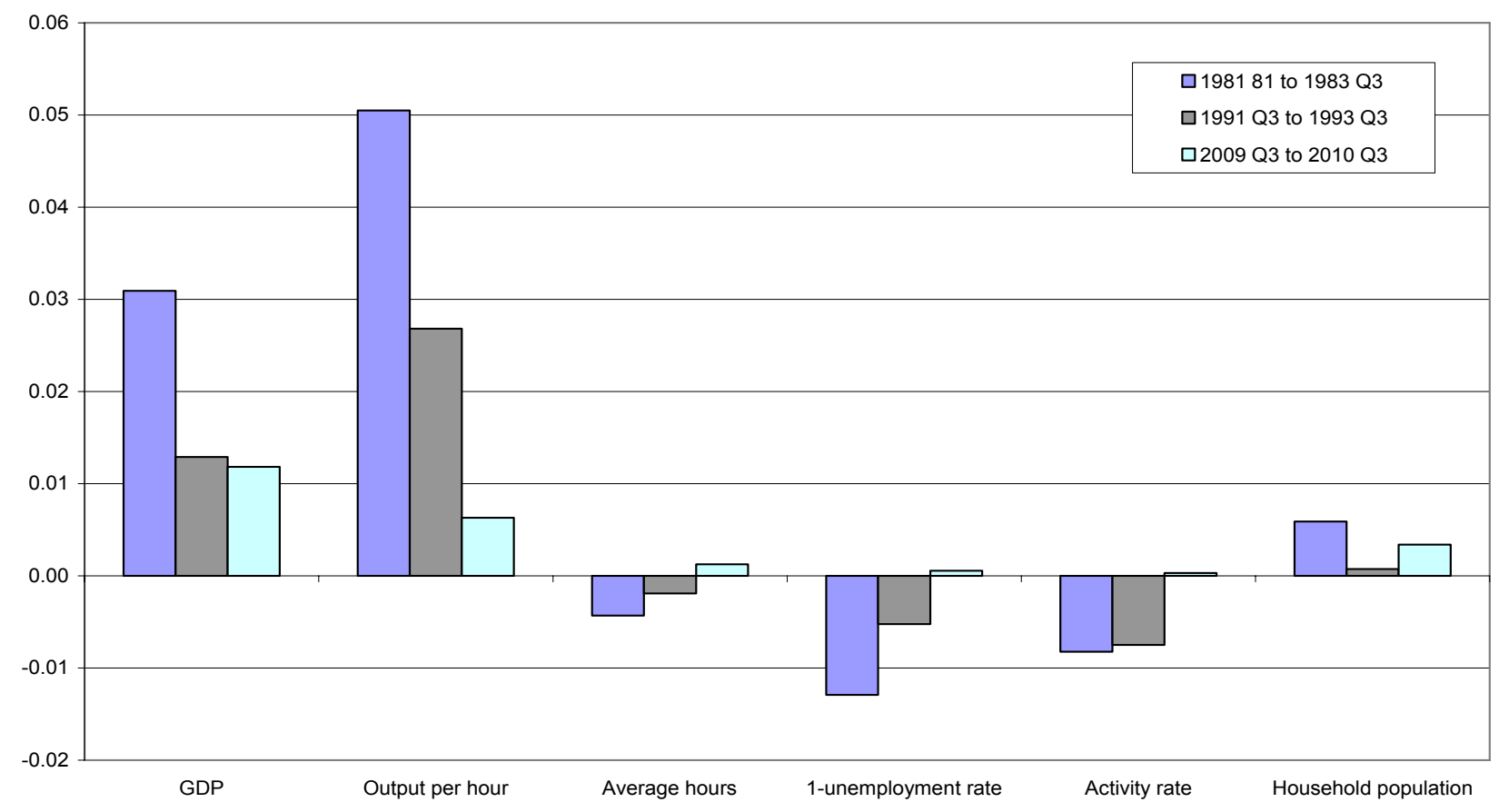


Again, the most interesting difference between the latest recovery and those of the early 1980s and early 1990s is centred on output per hour, which contributes significantly less this time. This is partly because in both the two previous recessions the labour market continued to weaken even though GDP was growing, as evidenced by further increases in the unemployment rate and falls in the activity rate (discouraged worker effects). Rising unemployment and falling activity have stabilised earlier in the recent recession, but as a consequence, output per hour has contributed less.

As mentioned already, output per hour is rather like a residual in this growth accounting approach - it includes the elements that are unmeasured such as the contribution of capital to labour productivity and rates of labour utilisation. As capital inputs are quasi-fixed in the short run, the main driver of output per hour is therefore likely to be rates of labour/capacity utilisation. The evidence here suggests that lower increases in the rate of unemployment in the recent recession have been bought at the price of using labour less intensively.

This outcome tends to suggest that firms have been hoarding labour to a greater extent than in previous downturns. Labour hoarding is not a completely irrational response to an economic downturn, especially because businesses tend to invest significantly in firm-specific capital and certain skills are in limited supply - meaning that if a downturn is temporary businesses have more to lose by releasing valuable labour that it will require in the future than using this labour less productively in the short-term. Business' ability to hoard labour has been aided by low interest rates and relatively good profitability coming into the recession - reducing the imperative of firms to reduce labour costs in order to preserve cash flow. However, whilst this is undoubtedly a good thing, it does suggest that firms may have added scope to increase output via productivity gains rather than through employment increases, which could result in a muted employment response to a recovery in GDP.

\section{Concluding comments}

The economic and social impacts of rising unemployment are of key concern to almost everybody. Therefore, during a recession, when output can often fall swiftly, the pass-through to the labour market becomes of paramount interest. This article has explored the relationship between output and unemployment by revisiting various aspects of Okun's Law.

It is clear that longer-term movements in the unemployment rate are driven by both cyclical and structural effects which has reduced the significance of Okun's Law as a forecasting rule of thumb. Due to structural changes in the relationship between output and unemployment over time, past experiences tend to be of limited value in explaining the present. However, on a short-term basis, looking at the differences in unemployment changes across different constituents of the labour market and across countries is still an interesting exercise.

The relationship between output and unemployment is more complicated or multi-faceted than Okun's Law allows for. This is shown in the production function approach in the final section of the article - where it is suggested that the weaker pass-through from the fall in GDP to the rise in the unemployment rate in the most recent recession compared to those of the early 1980s and early 
1990 s is due to lower labour productivity - or a sign of increased labour hoarding. This may have benefits in the short run by limiting the immediate rise in unemployment, but could lower the scope for future employment increases in the immediate future if businesses can produce more output by using existing labour more intensively.

\section{Contact}

elmr@ons.gov.uk 